logos_i_ethos_2016_1_(41), s.7-34

DOI: http://dx.doi.org/10.15633/lie.1791

Krzysztof Kaczmarczyk

\title{
Substytucja Lévinasa - substancjalna służba innemu?
}

\author{
„Ja jako Ja jest sługą Ty..."1
}

(E. Lévinas)

„Substytucja”, czyli dosłownie „podstawienie” czy „zastępstwo", nie należy do codziennego języka opisującego nasze doświadczenie moralne. Stąd też niełatwo ją intuicyjnie uchwycić, a co za tym idzie, filozoficznie przedyskutować. U Lévinasa natomiast zdaje się ona leżeć w samym centrum etyki, jako właściwie jedynie adekwatna postawa wobec spotkanej twarzy innego. Aby móc

Krzysztof Kaczmarczyk - absolwent filozofii Katolickiego Uniwersytetu Lubelskiego oraz francuskiej École Saint Jean. Obecnie doktorant na Uniwersytecie Papieskim Jana Pawła II w Krakowie. Nauczyciel etyki w krakowskim gimnazjum. Tłumacz m.in. M.-D. Philippe’a, Pielgrzymowanie filozoficzne. List do przyjaciela, Lublin 2003 oraz (wraz z innymi), na język francuski: La phénoménologie polonaise et le christianisme, dir. K. Tarnowski, Paris 2015. Interesuje się filozofią Arystotelesa.

się przyjrzeć temu tajemniczemu fenomenowi, zidentyfikować go we własnym życiu i ewentualnie docenić jego wartość (bądź poddać krytyce), pomocne będzie - jak mi się wydaje - zestawienie go z dwiema, bliższymi nam, postawami etycznymi: miłością i służbą.

Mój plan jest następujący: a. najpierw przyjrzę się miłości i jej różnym postaciom: od pożądania i erosa, przez życzliwość, przyjaźń i miłość oblubieńczą, aż do religijnych postaw miłosierdzia i chrześcijańskiej agape. Szczególnie interesujące będzie przyrównanie substytucji do tych ostatnich, niejako „odgórnych” (religijnych) form relacji miłosnych:

1 Por. E. Lévinas, komentując M. Bubera w: O Bogu, który nawiedza myśl [dalej: BNM], tłum. M. Kowalska, Kraków 2008, s. 252. 
pokazanie wielu punktów wspólnych, ale przede wszystkim dzielących je różnic; b. następnie - i to będzie moja teza - postaram się pokazać, że substytucję można całkiem dobrze zrozumieć w ramach kategorii służby. Oczywiście nie jakiejkolwiek, ale tej religijnej, a ściślej: mesjańskiej. Co by to miało jednak oznaczać? Jakie są warunki, a jakie jej konsekwencje? Czy mogę być tym, który bierze na siebie winy drugiego? I czy mogę to uczynić bez miłości? O jaką miłość musiałoby wówczas chodzić? Tego typu kwestie mam nadzieję nie tyle rozwikłać, co do pewnego stopnia naświetlić.

Zanim przejdę do moich rozważań, kilka uwag o charakterze meta-poznawczym. Niniejsze analizy mają profil raczej etyczny niż metafizyczny. Lévinas powiedziałby, że interesują mnie relacje międzyludzkie i codzienne postępowanie etyczne, czyli - jak sam to określa - psychologiczny aspekt substytucji ${ }^{2}$, nie zaś etyka jako filozofia pierwsza ${ }^{3}$. Niech będzie. Nie tu miejsce na rozstrzyganie, jak daleko sięga etyka. Ważne, że można zidentyfikować pewien wstępny obszar interesującego nas codziennego doświadczenia i to, jak się do niego odnosimy. Chciałbym się skupić na tym właśnie etapie, pozostawiając zejście w metafizyczny sens (tak znaczenie, jak i kierunek) ludzkiego istnienia dalszym rozważaniom. Wychodzę bowiem z założenia, że pierwsza, podstawowa, a zarazem poniekąd jedyna możliwość weryfikacji ewentualnych późniejszych rozstrzygnięć, także metafizycznych, leży na gruncie ludzkiego doświadczenia: doświadczenie etyczne jest nam bliższe, powszechniejsze i stąd pierwsze względem czegoś, co mogłoby nosić miano „doświadczenia metafizycznego" (jest to szczególnie jaskrawe w naszych „antymetafizycznych" czasach). Choć więc kwestie metafizyczne będą miały własny, autonomiczny punkt wyjścia, pozostają one, chcąc nie chcąc, zakorzenione w poznawczo przystępniejszych doświadczeniach (zresztą nie tylko etycznym, ale przede wszystkim pojetycznym, a także politycznym)

2 Por. BNM, s. 176.

3 E. Lévinas, „Odniesienie metafizyczne, odniesienie do tego, co zewnętrzne nie jest możliwe inaczej niż jako odniesienie etyczne" (Liberté et commandement [dalej: LC], Montpelier 1994, s. 44 , cytaty z LC podaję w moim tłumaczeniu). Por. także książkę o takim właśnie tytule: Éthique comme philosophie première [dalej: EPP], Paris 1998. 
i nie będą mogły od nich abstrahować pod groźbą utraty swego egzystencjalnego charakteru4.

Idąc dalej tym torem, można powiedzieć, że interesująca ostatecznie Lévinasa relacja $z$ Całkiem Innym, choć mogłaby ewentualnie posiadać własny punkt zaczepienia (w postaci jakiegoś specyficznego doświadczenia religijnego, czy też innego, metafizycznego punktu wyjścia), będzie $\mathrm{z}$ konieczności zabarwiona w swoim przeżywaniu warunkującymi je wcześniejszymi niereligijnymi doświadczeniami ludzkimi, w tym przypadku „doświadczeniem” innego. W sytuacjach skrajnych np. w przypadku traumatycznego doświadczenia fizycznej czy psychicznej przemocy, czy też w ogóle przy braku jakiegokolwiek fundamentalnego doświadczenia, np. bycia bezwarunkowo kochanym - może dojść do zaciemnienia, zniekształcenia, czy wręcz uniemożliwienia innych doświadczeń tak „ludzkich”, jak i „,religijnych”. Najczęściej jednak mamy do czynienia z za- czy prze- barwieniem obecnego już jakoś „doświadczenia" religijnego czy metafizycznego, które własną mocą może się powoli oczyszczać z różnych naleciałości w postaci narzucających się obrazów, np. dominującego ojca czy nadopiekuńczej matki. Do tego teoriopoznawczego wątku jeszcze wrócę przy okazji omawiania postawy miłosierdzia.

U Lévinasa interesujące będzie zabarwienie jego relacji z Innym doświadczeniem pomocy, wybawienia czy ocalenia innego (a więc służby). Samo religijne - w tym przypadku judaistyczne - tło jego myśli, choć ewidentnie nie bez wpływu, akurat tej służebnej opcji moim zdaniem nie wyjaśnia: wszak nie wszyscy żydowscy myśliciele - wystarczy wspomnieć dialogicznego Bubera - $\mathrm{w}$ ten sposób przeżywali i opisywali relację z innym! Stąd tak ważny będzie „przyziemny” opis tejże relacji oraz taka właśnie praktyczna analiza. Brak zgody na tym polu będzie decydujący

4 W tym punkcie idę za francuskim filozofem i teologiem o. Marie-Dominique Philippe'em (por. np. M.-D. Philippe, Filozoficzne pielgrzymowanie. List do przyjaciela, tłum. K. Kaczmarczyk, Lublin 2003, czy też Retour à la source, t. 1 i 2, Paris 2005 i 2009). Przywołuje on w tym kontekście, wykorzystane także przeze mnie, Arystotelesowe rozróżnienie na ordre génétique (porządek genezy, powstania), w którym pierwsza będzie filozofia sztuki i etyka, oraz ordre de perfection (porządek doskonałości), w którym pierwszeństwo przynależy metafizyce, stąd właśnie zwanej filozofią pierwszą. 
dla dalszych rozstrzygnięć. Nie oznacza to oczywiście, że wiele elementów zawartych w opisie doświadczenia etycznego, stawiając opór niniejszym rozważaniom (tj. nie znajdując w nich satysfakcjonującego wyjaśnienia), nie będzie domagać się innej, głębszej, metafizycznej analizy, przyznając tym samym owemu badaniu status filozofii pierwszej, już nie czasowo i „genetycznie” - jak w przypadku etyki - ale co do głębi, radykalności, czyli doskonałości ${ }^{5}$. O tym jednak - jak już wspomniałem - innym razem. Teraz czas na zejście do empirii. To tu dyskusja z Lévinasem będzie najbardziej fundamentalna, a zarazem najciekawsza.

Choć idea substytucji była obecna już we wcześniejszych pismach tego filozofa, to szczegółowego omówienia doczekała się dopiero w Inaczej niż być c $^{\mathrm{W}} \mathrm{W}$ poświęconym jej specjalnie rozdziale określa on tę postawę między innymi jako: „bierność doznawaną w bliskości innego we mnie, bierność cofania się do siebie poza sobą, która nie jest jednak alienacją zdradzonej tożsamości”" a także jako „komunikację między jednym i Drugim oraz - choć obie te relacje mają odmienny sens - między Drugim a jednym"8. A więc jakaś bierność, jakieś doznanie, jakaś relacja z innym powodująca we mnie zmianę. Bierność, i to - jak się okaże - pozbawiona wszelkiej aktywności; relacja dwustronna, ale nie wzajemna; radykalna zmiana, ale nie alienacja. Czyżby jakaś, może nieodwzajemniana, ale jednak miłość? Zacznę od porównania tych dwóch pozytywnie radykalnych (bo taką też jest substytucja) postaw wobec drugiego człowieka: tak na gruncie myśli samego Lévinasa, jak i wychodząc poza jej teren.

5 Chodzi o takie zagadnienia, jak możliwość dotarcia do substancji drugiego poprzez twarz, postawienie pytania o ontyczny status idei nieskończoności i jej relację z pojęciem aktu, a także o przeddecyzyjny, niejako zastany, charakter doznania dobra, odsłonięty właśnie przez substytucję, jako możliwą czy wręcz konieczną nań odpowiedź. Por. przyp. 4.

6 Por. E. Lévinas, Inaczej niż być lub ponad istota [dalej: IB], tłum. P. Mrówczyński, Warszawa 2000, zwłaszcza rozdział IV poświęcony właśnie substytucji, z którego - jak sam Lévinas wyznaje - wyrosła następnie cała, najważniejsza po Całości i nieskończoności - książka. Pierwotną, krótszą wersją tego rozdziału był artykuł Lévinasa pt. Substytucja zamieszczony w „Revue Philosophique de Louvain” 91 (1968), s. 487-507; jego polskie tłumaczenie ukazało się w książce Filozofia odpowiedzialności XX wieku, red. J. Filek, Kraków 2004, s. 215-235.

7 IB, s. 192.

$8 \quad$ IB, s. 201, przyp. 28. 


\section{Czy substytucja jest miłością? Jeśli tak, to jaką??}

Lévinas w swoich pismach mówi o miłości, jednak ostatecznie dość skrzętnie unika tego słowa na określenie swoistej relacji z innym. Przede wszystkim relacja miłości jest dla niego zbyt ambiwalentna: zawiera w sobie pomieszanie potrzeby z pragnieniem, nie oddając tym samym tego, o co mu chodzi ${ }^{9}$. Co więcej, uważa, że to „wyświechtane” dziś słowo, może prowadzić do niepotrzebnych nieporozumień ${ }^{10}$. Niekiedy jednak mówiąc o życiu prawdziwie ludzkim, a więc o relacji z innym, używa określenia „miłość bliźniego" (amour du prochain) ${ }^{11}$, jak gdyby ostatecznie właśnie tę biblijną wizję miłości miał cały czas na uwadze.

Spróbujmy więc pokusić się o krótki przegląd różnych znaczeń „miłości” pod kątem ich „zgodności” z substytucją:

- z całą pewnością w substytucji nie idzie ani o miłość instynktowną (pociąg seksualny czy pragnienie pokarmu), ani o zwykłą miłość uczuciową (uczucie miłości), ani też o idealizujący drugiego stan zakochania;

- nie jest to też miłość-eros, która u Lévinasa jest spotkaniem męskości z kobiecością: nie z innym jako innym, ale z innym jako danym w czasie $^{12}$;

- a może chodzi mu o szacunek czy życzliwość, będące jakimś początkiem, zalążkiem miłości? czy też o odnoszącą się do wszystkich filantropię? ${ }^{13}$;

9 Dobrze to oddaje ocierające się o sprzeczność określenie miłości jako jouissance $d u$ transcendant, czyli „rozkoszowanie się [bytem] transcendentnym” (E. Lévinas, Całość i nieskończoność. Esej o zewnętrzności [dalej: CN], tłum. M. Kowalska, Warszawa 2002, s. 307).

10 „Jestem nieufny w stosunku do słowa miłość, które jest używane bez pokrycia” (E. Lévinas, Etyka i Nieskończony [dalej: EN], tłum. B. Opolska-Kokoszka, Kraków 1991, s. 33).

$11 \quad$ EN, s. 67.

12 Por. EN, s. 38-39 oraz całą analizę kobiecości w: E. Lévinas, Le temps et l'autre, Paris 1991. Sam Lévinas określa relację odpowiedzialności za innego jako miłość bez erosa. Por. BNM, s. 46, 143; EN, s. 65. Jednocześnie kobiecość jest dla niego „źródłem samego pojęcia inności” (EN, s. 40).

13 Lévinas wyraźnie mówi o tym, że twarz drugiego otwiera mnie na całą ludzkość, rozumianą jednak nie jako rodzaj ludzki czy anonimowa zbiorowość (por. CN, s. 368), ale jako braterstwo w człowieczeństwie: „Epifania twarzy jako twarzy otwiera na człowieczeństwo” (CN, s. 252). 
- czy można tu mówić o miłości-filia? Raczej nie. Przyjaźń zostaje przez Lévinasa uznana za niezdolną do zdania sprawy z relacji z innym ${ }^{14}$;

- czy nie ma w niej czegoś z Wojtyłowej miłości oblubieńczej: całkowitego oddania się drugiej osobie?;

- a może jest to rodzicielska miłość troszcząca się o drugiego jak o kogoś, kogo się ma pod swoją opieką ${ }^{15}$ ?;

- albo raczej czy nie jest to biblijna miłość wobec uciśnionych, jakaś religijna postawa miłosierdzia względem potrzebujących ${ }^{16}$ ?;

- może wreszcie ma ona coś wspólnego z miłością-agape, o której piszą Ewangelie, szczególnie Janowa - przecież jest to miłość, która oddaje życie za braci i kocha nawet nieprzyjaciół.

Wydaje się, że ze wszystkich typów miłości najlepiej współgrają z substytucją te ostatnie postawy. Ich podwójny radykalizm: horyzontalny (brak „względu na osoby”, w tym także na siebie) oraz wertykalny (otwarty, ale i otwierający na „to, co z wysoka” ${ }^{17}$ ) zdają się nieźle wpisywać w Lévinasowską relację z innym. Przypatrzmy się jednak nieco bliżej owej „niepotocznej” - także na gruncie języka francuskiego - substitution.

Na początku należy podkreślić, że substytucja jest jakąś odpowiedzią (a więc jakimś „skutkiem”) na wtargnięcie innego w mój świat, we mnie - co ma miejsce gdy staję face à face $\mathrm{z}$ drugim człowiekiem ${ }^{18}$. Inny przerasta moją tożsamość - choć go goszczę - oto niosę w sobie transcendencję, będąc „mniej zawierającym więcej”" ${ }^{\prime 1}$. Wobec takiej re-wolty zostaję według Lévinasa zobowiązanym, stając się zakładnikiem

14 Krytykując Bubera, Lévinas pisze: „Ja-Ty jest wydarzeniem (Geschehen), zderzeniem, rozumieniem - ale nie pozwala zdać sprawy z życia nie mającego struktury przyjaźni [...]: z ekonomii, poszukiwania szczęścia, przedstawieniowej relacji z rzeczami” (CN, s. 66).

15 Na temat tego, jednego z kluczowych, jak się wydaje, dla Lévinasa uczuć por. przyp. 53.

16 Stałym przykładem innego jest - niosący w sobie pewną nędzę - biblijny obcy, ubogi, sierota i wdowa, por. CN, s. 77, 78, 256, 295, 302.

17 Por. E. Lévinas, Transcendance et hauteur, [w:] LC, s. 69.

18 Por. CN, s. 9, 38n; IB, s. 249.

19 Por. BNM, s. 141. Por. także: „To Samo zawiera więcej, niż może zawrzeć” (BNM, s. 161). 
drugiego $^{20}$. Nie ma tu mowy o jakiejś satysfakcji czy ukojeniu w spotkaniu $\mathrm{z}$ innym (postawy te przynależą do porządku juissance, w której używam, korzystam, żyję drugim). Chodzi jedynie o to, by żyć dla drugiego. I żyć tak bardzo dla niego, żeby nie tylko go nie zabić (oczywiście nie tylko fizycznie, ale i moralnie, przez sprowadzenie go do siebie ${ }^{21}$ ), ale by być gotowym dać się zabić za niego (czyżby także aby dać sprowadzić się do niego?): podstawić swoje życie za jego życie, swoje „ja” za jego „ja” - dokonać substytucji ${ }^{22}$. „Wszystkim jesteśmy winni własne życie"23. Innemu zaś winienem wszystko ${ }^{24}$.

Jak określić taką postawę? Czy nie mamy tu do czynienia - jak by się na pierwszy rzut oka mogło wydawać - z jakimś chorobliwym poczuciem winy: żyję tylko dlatego, że ktoś inny zginął, że oddał za mnie życie? Czy nie jest to syndrom dziecka ocalonego, które musi czynić wszystko, by usprawiedliwić własną egzystencję? Czy taka postawa nie prowadzi do służenia innym własną egzystencją, chciałoby się powiedzieć, czy sub-stytucja nie prowadzi do jakiejś egzystencjalnej pro-stytucji ${ }^{25}$ ?

Oczywiście wpływ, jaki na Lévinasa miały straszliwe doświadczenia wojny, jest niezaprzeczalny: zresztą sam autor to potwierdza ${ }^{26}$. Jest to więc filozofia w cieniu Holokaustu. Jednak pretendujący do pewnej uniwersalności (choć swoiście rozumianej ${ }^{27}$ ) filozof każe nam na te same po-

20 Por. m.in. IB, s. 188, 198; EN, s. 56; BNM, s. 61. Można to określić jako przejście od posiadania siebie (possession de soi) do bycia posiadanym przez innego (obsession par l'autre), por. IB, s. $166-171$.

${ }^{21}$ Por. CN, s. 288; bądź przez zajęcie jego miejsca na ziemi, por. EN, s. 66n. Por. także przyp. 77.

22 Por. np. BNM, s. 150.

23 F. Dostojewski, Bracia Karamazow, Warszawa 1984, księga VI, II a, s. 87.

24 „Gdybyśmy mieli przed sobą tylko drugiego człowieka, doprowadziłbym rzecz do końca: jestem mu winien wszystko. Jestem dla niego" (BNM, s. 165).

25 Prosto, prostiti (łac.) - być wystawionym na sprzedaż, prostituo - oddawać się nierządowi.

26 Por. E. Lévinas, Trudna wolność [dalej: TW], tłum. A. Kuryś, Gdynia 1991, s. 138n. Por. także CN, s. 3-4, 7.

27 Można by powiedzieć, że powszechność według Lévinasa nie polega na znalezieniu jakiegoś ogólnego pojęcia, logosu czy reprezentacji (por. IB, s. 216-217), ale na odpowiedzialności za wszystkich ludzi, na dźwiganiu wszechświata, a tym samym na usensawnianiu samego bytu! „To 
stawy spojrzeć inaczej, jak się wydaje mniej redukująco: w perspektywie religijnej. Do tego zresztą zostaje zaproszony każdy, kto Lévinasa czyta: po rozszczepieniu własnej całościowej tożsamości przez nieskończoność innego (por. Całość i nieskończoność, 1971) człowiek opuszcza niejako dotychczasową kondycję bytu (staje się bez-inter-essowny) po to, by żyć etycznie: być bezgranicznie i obsesyjnie odpowiedzialnym za drugiego (por. Inaczej niż być, 1978). Takie wystawienie się na innego, taka bierność i doznawalność oznacza palące Pragnienie, w którym myśl „wydana jest na myślenie więcej niż myśli”28, na Boga - który jeśli ma jakiś sens jest Upragnionym, ale i Świętym, tak oddzielonym, że Nie-upragnionym, Innym inaczej niż inny ${ }^{29}$ (por. O Bogu, który nawiedza myśl, 1982).

Ta religijna, miejscami wręcz mistyczna, perspektywa zdaje się tłumaczyć wcześniejsze trudności, ale czy do końca? Owszem, Lévinas zbliża się tu najbardziej do chrześcijańskiej miłości-agape, w której bliźni kochany jest niejako samą miłością Boga: „aż do oddania życia za braci”, „nie mając względu na osoby"30. Liczy się tu - można by rzec - przede wszystkim miłość Boża, Boże dotknięcie, które pozwala widzieć w drugim - czytaj: w jego twarzy - samego Boga, przymuszając niejako do miłowania go. Czyż Chrystus nie mówi: „co uczyniliście jednemu z tych braci najmniejszych, Mnieście uczynili” (Mt 25, 40)? Zresztą opis miłości Upragnionego niejednokrotnie zbliżony jest do opisu szalonej miłości Boga u takich chrześcijańskich mistyków, jak Jan od Krzyża czy Teresa z Ávila ${ }^{31}$.

dzięki Sobości i substytucji bycie będzie miało sens... Bycie będzie miało sens jako wszechświat, a jedność wszechświata będzie we mnie o tyle, o ile jestem zobowiązany być. Znaczy to, że przestrzeń wszechświata ukaże się jako domostwo innych. Pra-geometryczny eidos przestrzeni zostaje opisany jako zamieszkany przez innych, którzy patrzą na mnie i mnie obchodzą. Ja podtrzymuję wszechświat. Sobość nie stanowi tylko o jedności ludzkiej społeczności - jednej w mojej odpowiedzialności - ale także o jedności bycia” (IB, s. 201, przyp. 27). Por. także CN, s. 76 oraz IB, s. 195n.

28 „Oślepienie, przy którym oko wytrzymuje więcej, niż może wytrzymać; poparzenie skóry, która dotyka i nie dotyka tego, co ją parzy, wykraczając poza zwykłą uchwytność. Bierność, czyli pasja, rodząca Pragnienie, kiedy «więcej w mniej» budzi swym płomieniem najgorętszą, najwznioślejszą i najstarszą myśl, która myśli więcej niż myśli” (BNM, s. 141).

29 BNM, s. 144-145.

30 Por. 1 J 3, 16; Mt 22, 16; Rz 2, 11; Jk 2, 9.

31 Por. np. BNM, s. 143: „Pragnienie wywołane przez Nieskończoność nie może zmierzać do żadnego celu: w Pragnieniu zbliżanie się jest oddalaniem, a używanie wzmaga 
Analogię można ciągnąć dalej: tak jak jednym z pierwszych owoców miłości-agape jest służba, i to tak radykalna, że nieraz określa się ją mianem niewoli ${ }^{32}$, tak i tu wtargnięcie innego skutkuje naszą substytucją. Czyż Lévinasowskie ,jeden za drugiego" ${ }^{\prime 3}$ nie pobrzmiewa ewangelicznym ,jeden drugiego brzemiona noście" $(\mathrm{Ga} 6,2)$ ?; a poddanie się drugiemu (être assujetti) nie przypomina pokornej i służebnej postawy, do jakiej Paweł nawoływał chrześcijan z Filippi ${ }^{34}$ ?

Oprócz tych niewątpliwych podobieństw nie można nie dostrzegać zasadniczych różnic: branie na siebie brzemion bliźnich dokonuje się jak wierzą chrześcijanie - poprzez uczestnictwo w cierpieniu Jezusa, który będąc Mesjaszem (Chrystusem) jako jedyny „skutecznie” wziął na siebie „grzech świata" ${ }^{35}$. Tak więc w ścisłym tego słowa znaczeniu

głód”. Por. także CN, s. 19. Co do podobieństwa z doświadczeniem mistycznym przychodzi tu na myśl chociażby Pieśń duchowa św. Jana o Krzyża, w której zakosztowanie duchowej obecności Boga w duszy powiększa żarliwość i pragnienie ujrzenia Go (strofa 11) lub też opisana w Żywym Płomieniu miłości (II, 6) powstała z miłosnego upalenia rana w duszy, która im głębiej zraniona, tym zdrowsza: „lekarstwem na miłość jest ciągłe powiększanie i odnawianie zadanej rany, aż do tego stopnia, by rana stała się tak wielka, iżby objęła i zamieniła duszę w jedną ranę miłości” (Jan od Krzyża, Dzieła, tłum. B. Smyrak, Kraków 1986, s. 743). Jednak czy ujrzenie i zjednoczenie z Upragnionym nie oznacza koniecznie ustania pragnienia? Tego obawia się Lévinas. Ciekawą odpowiedź daje tu św. Tomasz z Akwinu, dla którego nawet w szczęśliwym widzeniu Boga twarzą w twarz - choć spełnia ono wszelkie pragnienie człowieka („omne desiderium hominis completur”) - Bóg nie daje się całkowicie objąć ludzkiemu umysłowi, także temu oświeconemu światłem chwały. Tym samym poznając samą istotę Boga, pozostaje jednocześnie w wiecznym stanie podziwu, któremu towarzyszy radość, będąca odpowiednikiem (odwrotnością) ziemskiego pragnienia (por. Summa contra gentiles, III, 55-63, szczególnie III, 62, 9; por. także: Summa theologiae, I, 12, 7 i 8; I-II, 3, 8).

32 Por. chociażby: L.-M. Grignion de Monfort, Traktat o prawdziwym nabożeństwie do Najświętszej Maryi Panny, Warszawa 1996, passim. Także w Nowym Testamencie doulos - odnoszące się wielokrotnie do uczniów Chrystusa (por. Mt 20, 27; Dz 4, 29), do Maryi (Łk 1, 38. 48), a nawet poniekąd do samego Jezusa, przynajmniej co do Jego „postaci” (Flp 2, 7) lub postępowania (J 13, 1-17) - to zarówno sługa, jak i niewolnik.

33 Por. np. IB, s. 229n.

34 „To dążenie niech was ożywia; ono też było w Chrystusie Jezusie. On, istniejąc w postaci Bożej, nie skorzystał ze sposobności, aby na równi być z Bogiem, lecz ogołocił samego siebie, przyjąwszy postać sługi, stawszy się podobnym do ludzi. A w zewnętrznym przejawie, uznany za człowieka, uniżył samego siebie, stawszy się posłusznym aż do śmierci - i to śmierci krzyżowej” (Flp 2, 5-8).

35 Por. „Oto Baranek Boży, który gładzi grzech świata” (J 1, 29). Konkretnym „przejawem” zgładzenia grzechu świata jest - najbardziej kontrowersyjna, a centralna dla chrześcijań- 
jedynym odpowiedzialnym za winy drugiego stał się Jezus: „wszyscy bowiem zgrzeszyli", ściągając na siebie śmierć ${ }^{36}$, On natomiast - dla naszego usprawiedliwienia - zgodził się na to, by dla nas stać się grzechem ${ }^{37}$. Tak więc „w Chrystusie” nie jestem już za wszystko odpowiedzialny, winny (coupable). Jestem wolny, a jednocześnie zaproszony do wejścia w Jego posługę, do współcierpienia, do solidarności, do miłosierdzia, aż po oddanie życia ${ }^{38}$. Jednak nigdy swoją mocą, nigdy w swoim imieniu: byłoby to zabójcze ${ }^{39}$.

Czy jednak postawa miłosierdzia i współczucia nie ma żadnego sensu poza Chrystusem? Takie postawienie sprawy wydaje się przesadzone. Można o niej chyba mówić nawet w perspektywie filozoficznej, szczególnie mądrościowej, jako o jednym z konkretnych owoców miłującej kontemplacji. Tak przynajmniej stawia sprawę Philippe.

Odróżnia on „zwykłe” miłosierdzie i współczucie - będące odruchem serca, często „jedynie” litością, od miłosierdzia wypływającego

stwa - Jezusowa władza odpuszczania grzechów potwierdzana znakami (por. np. Łk 5, 17-26; 7, 36-50) i przekazana Dwunastu (J 20, 23). Dobrze streszcza tę prawdę wiary św. Paweł: „W Nim mamy odkupienie przez Jego krew - odpuszczenie występków, według bogactwa Jego łaski" (Ef 1, 7, por. także $1 \mathrm{~J} 2,2$ ).

36 Por. Rz 5, 12.

37 Por. 2 Kor 5, 21.

38 Por. np. „Po tym poznaliśmy miłość, że On oddał za nas życie swoje. My także winniśmy oddać życie za braci” (1 J 3, 16), a z drugiej strony: „Ku wolności wyswobodził nas Chrystus. A zatem trwajcie w niej i nie poddawajcie się na nowo pod jarzmo niewoli” (Ga 5, 1). Warto zwrócić uwagę, jak słowa te mają być realizowane w praktyce, np. pomocy innym: „Nie o to bowiem idzie, żeby innym sprawiać ulgę, a sobie utrapienie, lecz żeby była równość” (2 Kor 8, 13); oraz „Każdy niech przeto postąpi tak, jak mu nakazuje jego własne serce, nie żałując i nie czując się przymuszonym, albowiem radosnego dawcę miłuje Bóg” (2 Kor 9, 7). Podstawową zasadą jest tu, jak widać: „Darmo otrzymaliście, darmo dawajcie” (Mt 10, 28).

39 Według Lévinasa natomiast mamy tu do czynienia z pewnego rodzaju - jak mi się zdaje - paradoksem: choć nie jestem zdolny do wynagrodzenia za cudze winy („Le Moi n’est pas un étant «capable» d'expier pour les autres", por. IB, s. 200) okazuje się, że jestem samą tą pierworodną ekspiacją! To przed-dobrowolne branie na siebie ciężaru drugiego, owa pierwotna bierność, „winność”, odpowiedzialność, „bycie-dla” stanowią prawdziwą „tożsamość”, „istotę”, „substancję”, prawdziwy rdzeń mojego ja, oraz - już bez cudzysłowu - jego dobroć (będącą jednak wielkością negatywną, por. IB, s. 189), okazującą się ostatecznie posłuszeństwem ukrytemu Dobru (por. IB, s. 199, 214, 238). Por. także przyp. 90. 
z kontemplacji ${ }^{40}$. Pierwsze, choć zasadniczo jest cechą pozytywną, przeciwną zatwardziałości i obojętności na cierpienia bliźnich, pozostaje jednak często uczuciem przelotnym, zależnym od naszego temperamentu i relacji afektywnych z rodziną i przyjaciółmi. Na dłuższą metę jest też nieskuteczne w pomocy: nędza drugiego nie jest łatwa do niesienia i po jakimś czasie zaczyna ciążyć. Bez głębszej perspektywy łatwo jest uciec, przejść obok. Dopiero dzięki kontemplacji Boga ta krucha inklinacja może się stać prawdziwą cnotą, analogiczną do cnoty religijności: „tak jak ona utwierdza nas (nous fixe) w transcendencji Boga-Stwórcy, tak [w miłosierdziu] przyciągani jesteśmy przez nędze braci tak bardzo, że niemożliwe staje się opuszczenie ich, ominięcie i cieszenie się życiem, w którym oni nie mają udziału"41. Philippe wymienia trzy elementy konstytuujące akt miłosierdzia:

a. Konieczne jest poznanie nędzy (misère) drugiego, jednak nie teoretyczne, czysto intelektualne - to poznanie bywa nawet przeszkodą - ale praktyczne, afektywne. Co więcej: nie wystarczy poznać tylko nędzy, słabości, ubóstwa drugiego, trzeba jeszcze dojrzeć samego nędznego i ubogiego, jego osobę, w konkretnej egzystencjalnej sytuacji ${ }^{42}$.

b. Takie afektywne poznanie pozwala na pewnego rodzaju pokrewieństwo (współnaturalność) z ubogim: jego nędza staje się wówczas naszą nędzą, nosimy ją wewnątrz siebie jakby była nasza, nasze serce jej doświadcza, ona je boli. „Trzeba bardzo kochać nędznego - pisze Philippe - by dobrowolnie zgodzić się na upodobnienie się z nim w jego nędzy [...]. Sympatia płynąca z filantropii - dodaje - nie pozwala tak

40 Także dla Lévinasa odpowiedzialność za innego w jego nędzy nie oznacza litości! Według niego substytucję jestem drugiemu po prostu winien (zob. Transcendance et hauteur, dz. cyt., s. 69), i to tym bardziej, im bardziej tę nędzę dostrzegam i jej zaradzam: „Im lepiej wypełniam swój obowiązek, tym mniej mam praw; im jestem sprawiedliwszy, tym bardziej jestem winny" (CN, s. 296). Nieskończenie!

$41 \quad$ M.-D. Philippe, La philosophie de l'activité morale [dalej: AM], mps, Rimont, s. 236.

42 Por. AM, s. 237. Z takimi stwierdzeniami w pełni zgodziłby się Lévinas - takie jest w zasadzie przesłanie płynące z całej jego filozofii. Można tu dodać tylko tyle, że być może - według Lévinasa - twarz bliźniego w potrzebie pozwala dojrzeć w nim innego lepiej niż twarz ukochanego w relacji erotycznej, właśnie dzięki jego nędzy, lepiej ukazującej jego nie-byt, jego nieobecność, jego nagość (por. przyp. 52). 
naprawdę «doznawać», gdyż pozostaje uniwersalna i nie zostaje zindywidualizowana względem jakiejś konkretnej osoby"43.

c. Wreszcie konieczna jest siła do tego, by ulżyć cierpiącemu, by żyć jego nieszczęściem przy nim i razem z nim, pomagając mu uniknąć najgorszego, tj. rozpaczy - dzięki wydobyciu go z samotności. Cierpienie bowiem zamyka w sobie, stanowiąc tym samym dodatkowe obciążenie. Wydobycie z zamknięcia - choć konieczne - nie wystarcza. Trzeba jeszcze uwolnić drugiego od zła, które mu doskwiera ${ }^{44}$.

Jaki to wszystko ma jednak związek z kontemplacją? Otóż dzięki niej, dzięki miłości, która jej towarzyszy, (a którą Philippe zwie adoracją), zwykła życzliwość, łącząca nas z innymi ludźmi, zostaje pogłębiona, przekształcając się w hojność i wielkoduszność wobec tych, którzy okazują się - w tej nowej religijnej perspektywie - dziećmi jednego Boga, czyli jakoś naszymi braćmi i siostrami. Tym samym relacje sprawiedliwości zostają dopełnione i przekroczone przez nową miłość, wyrażającą się w sposób bardzo szczególny wobec zła dotykającego bliźnich, szczególnie słabych i bezbronnych.

Tyle o miłosierdziu. Czy taka religijna perspektywa pokrywa się w pełni z Lévinasowską substytucją jako fundamentalną strukturą postawy etycznej wobec innego? Zbieżność jest niewątpliwa. Pozostaje jednak pytanie: dlaczego koniec końców miałbym być winien drugiemu wszystko?

Tutaj przydatna będzie dygresja. Posłużenie się wstępnymi rozważaniami teoriopoznawczymi. Oto trzeba ustalić pewien porządek: według Lévinasa wtargnięcie innego umożliwia i prowadzi do otwarcia się na Innego ${ }^{45}$. W takim układzie, jeśli w ogóle Inny będzie jakoś poznawalny,

43 AM, s. 237. Pisząc o „obsesji“ na punkcie drugiego, Lévinas mówi, że jest ona „bardziej konkretna, niż coś, co jest tylko elementem całości” (IB, s. 188) oraz że wykracza nie tylko poza egoizm, ale i altruizm (por. IB, s. 199, 209, przyp. 34).

44 Por. AM, s. 237.

45 Lévinas mówi o tym wielokrotnie: „Wymiar boskości otwiera się w twarzy człowieka” (CN, s. 78n) lub: „W dostępie do twarzy istnieje z pewnością dostęp do idei Boga” (EN, s. 53) czy wręcz: „Przyjmując innego człowieka, przyjmuję Najwyższego...” (CN, s. 361). Za Pierre’em Hayatem można powiedzieć, że „Le rapport à Dieu prend sens à partir de la relation au visage de l'autre homme” (ze wstępu do LC, s. 15). Może warto tutaj wspomnieć o tym, skąd pochodzi idea Nieskończoności, którą Lévinas „się posługuje”, by mówić tak o innym, jak i o Innym. Nie muszę oczywiście wspominać, że nie 
to tylko przez odniesienie do innego, nie odwrotnie ${ }^{46}$. Posuńmy się krok dalej: nawet jeśli mielibyśmy tu do czynienia z jakimś doświadczeniem religijnym czy mistycznym, przed czym Lévinas się broni ${ }^{47}$, to i tak - jak już wspominałem - prędzej czy później będzie ono miało, moim zdaniem, koloryt i posmak wcześniejszego spotkania z innym. Dlaczego? Dlatego, że obudzi w nas i „przejdzie” przez to, co już w nas zastane. Ujmując to formalnie: wszelkie doświadczenie duchowe, nawet najbardziej mistyczne, uwarunkowane jest doświadczeniem ludzkim. Jeszcze dokładniej, w odniesieniu do łaski wiary, ujmuje to Philippe, stwierdzając, że: „wiara nie wnosi żadnego nowego pojęcia, a jedynie nowy sąd"48. W przeciwnym razie człowiek religijny operowałby nowymi pojęciami, które w języku ludzkiego doświadczenia by nie istniały, nie miałyby żadnego sensu. A tak nie jest: „inny”, „pragnienie”, „absolutne”, „dobro”, „współczucie”, „całość”, „nieskończoność” - wszystkie te pojęcia odnoszą się do naszego - owszem, szeroko rozumianego - ludzkiego doświadczenia i operacji na nim przeprowadzanych.

I wbrew pozorom nie jest to sprowadzanie doświadczenia religijnego do jakiejś projekcji czy idealizacji doświadczenia „ziemskiego”. Chodzi tylko o to - co za Sokratesem stwierdza sam Lévinas - że to, co boskie, nie jest dane bezpośrednio, ale jest drogą wychodzącą od tego, co na dole ${ }^{49}$. Bóg więc nie jawi się nam jako fenomen, lecz jako jego brak, jako

chodzi tu o „zwykłą" Kartezjańską ideę spekulatywną, ale o ideę, która jest duchową relacją i Pragnieniem (zob. CN, s. 39; EN, s. 53) oraz niezaspokajalnym (tj. nieskończonym) wymogiem świętości (zob. EN, s. 58). Otóż Lévinas pisze, że zostaje ona wzbudzona w nas przez le désirable (pisane co prawda enigmatycznie, raz dużą, raz małą literą) (zob. CN, s. 41), że jest otrzymywana od Bliźniego i przyjmowana od mistrza, który naucza w mowie (le dire) (zob. CN, s. 240) poprzez wyrażającą się twarz (zob. CN, s. 41-42, 244). Mamy tu więc do czynienia z jakimś subir, z jaką́s affection (BNM, s. 141). Lévinas stwierdza nawet, że - wbrew sokratejskiej majeutyce - przychodzi ona jak Arystotelesowy nous, zarazem z zewnątrz, ale i bez przemocy (zob. CN, s. 42), wślizguje się jak złodziej (zob. IB, s. 249, 252).

46 „Żadne «poznanie» Boga nie istnieje w oderwaniu od tych stosunków [z ludźmi] [...]. Właśnie nasze stosunki z ludźmi [...] nadają pojęciom teologicznym jedyne znaczenie, jakie one w ogóle posiadają" (CN, s. 79).

47 Por. np. CN, s. 364.

48 Myśl ta, często przywoływana przez tego francuskiego filozofa i teologa, choć - o ile mi wiadomo - nieobecna explicite w tekstach Akwinaty, pozostaje zgodna z linią Tomaszowej teologii.

49 Por. CN, s. 38. 
coś, co świta „między wierszami” czy raczej „między bruzdami twarzy” innego ${ }^{50}$, w jego bezbronnych oczach, w jego czarnych (pusto-pełnych), patrzących na mnie źrenicach ${ }^{51}$.

A więc droga. Droga „wzwyż”, czy jak kto woli „w głąb”, rozpoczynająca się od tego, co „tu, przede mną”. I dopiero potem powrót, zejście z góry, nowe, mądrościowe, religijne i np. miłosierne patrzenie na drugiego. W „świetle” Pragnienia.

Na pierwszy rzut oka na takim postawieniu sprawy można by poprzestać: substytucja byłaby niczym innym, jak postawą miłosierdzia, będącą owocem jakiegoś religijnego radykalizmu, jakiegoś imperatywu płynącego z dojrzenia Boga w twarzy innego. Takie postawienie sprawy rozwiązuje jednak nasz problem tylko częściowo.

Nie jest bowiem jasne, dlaczego ten właśnie imperatyw wysunął się na pierwsze miejsce, przyciemniając niejako wszystkie inne? Dlaczego Lévinas nie poszedł w kierunku jakiejś nowej „mistycznej” miłości bliźniego? Dlaczego twarz innego nie wzywa go przede wszystkim do dialogicznego spotkania we wzajemnej przyjaźni dzieci jednego Boga ${ }^{52}$ ?

50 „Jako ślad urywający się w śladzie, jako mniej niż nic w śladzie tego, co transcendentne [...], twarz bliźniego prześladuje mnie w swojej nędzy i ogołoceniu. «Patrzy na mnie», wszystko w niej dotyczy mnie, nic nie jest mi obojętne. Nic nie nakazuje w sposób bardziej kategoryczny niż to porzucenie w pustce przestrzeni, niż ślad nieskończoności, która przechodzi, nie mogąc wejść. W tym przejściu wyłania się twarz jako ślad nieobecności, jako pomarszczona skóra: w dwuznaczności piękna jest dziwnym tropem obecności, która pozostaje cieniem siebie samej, cieniem bytu, który w niepamiętnej przeszłości żłobi swój ślad” (IB, s. 157).

${ }^{51}$ Te zaczerpnięte od Jean-Luca Mariona uwagi przytacza Jacques Rolland we wstępie do wydanego w formie książkowej wspomnianego już wykładu Lévinasa Éthique comme philosophie première (zob. EPP, s. 48). Por. także LC, s. 41.

52 Można by, jak się wydaje, nawet na gruncie filozofii Lévinasa pomyśleć taką relację, która byłaby obustronną substytucją, niezatrzymującą się jednak na innym (tak mną, jak i drugim), ale kierującą się - i to ze zdwojoną siłą - ku transcendentnemu Innemu. Wówczas, paradoksalnie, Inny przychodziłby zarówno z zewnątrz, jak i z wnętrza relacji, z jej „pomiędzy”. Próbę takiego przekroczenia Lévinasa proponuje np. T. Tatranský, A reciprocal asymmetry? Levinas's ethics reconsidered, „Ethical Perspectives” 15 (2008) issue 3, s. 293-307. Tak rozumianą relację wzajemną, będącą zarazem miejscem odkrycia Boga, ustawia natomiast w centrum swojej etyki przywoływany już Philippe (por. M.-D. Philippe, Retour à la source, t. 2: De la science à la sagesse, dz. cyt., s. 109n, 151n). Co zatrzymało Lévinasa przed pójściem w tę stronę? Być może swoista koncepcja (a przed nią doświadczenie) miłości, niepozwalająca np. na dopuszczenie do relacji erotycznej, wystawienia się na braki 
Albo też dlaczego nie zdominował go strach przed innym i na przykład
Heideggerowski lęk (ucieczka), a może nawet trwoga ${ }^{53}$ ? Dlaczego substytu-
cja? Dlaczego właśnie jednokierunkowa, służebna, poddańcza substytucja?
Dochodzimy tu do sedna. Stwierdziliśmy już, że gdyby nie spotka-
nie innego, to na Innego prawdopodobnie otworzyć by się nie można.
A także: takie spotkanie z Innym, jakie spotkanie z innym ${ }^{54}$. Można więc

drugiego: na „ubogiego” mieszkającego w bracie, „sierotę” mieszkającą w synu, „wdowę” mieszkającą w kobiecie, jednym słowem na ograniczoność i kruchość uniemożliwiającą niezmąconą niczym satysfakcję i rozkoszowanie się drugim. Z drugiej strony może też chodzić o uniemożliwiającą przejście do wzajemności wizję miłości własnej. Czyż własnej, najgłębszej dobroci nie mogę odkryć tylko dzięki drugiemu, w jego twarzy, w jego oczach? Z takim „dobrym ja”, które nie jest dla drugiego tylko tu, ale i vous u Lévinasa się nie spotkałem. Najbliższe temu, o czym mówię, byłoby jego studium kobiecości. Kobiecość to zarazem obecność, jak i jej wycofanie, czyli umożliwiająca gościnę i bycie u siebie - a więc i jakieś przyjęcie siebie - dyskrecja. I choć jest to pewna défaillance de l'être, a więc „słabość w bycie”, umożliwia ona transcendentną relację z bliźnim. Nie jest to więc ułomność bytu, lecz jego zaleta, nie pęknięcie, ale raczej plastyczność (por. także przyp. 85). Z kolei w perspektywie religijnej można by pomyśleć o darzących się wzajemnie zaufaniem i sym-patią - a zarazem świadkach Transcendencji przyjaciołach; o swoistych towarzyszach drogi, którzy odkrywszy Coś więcej, niosą - każdy z osobna, choć współodczuwając jakoś razem - własne nędze, jak i nędze swoich braci. Dzięki Bogu.

53 Oprócz powyższych „uczuć” towarzyszących człowiekowi w jego byciu-w-świecie pojawiają się u Heideggera także - bliskie substytucji - troska i zatroskanie (o własne bycie, ale i o współbycie-z-innymi), a także fundamentalne poczucie bycia winnym. Por. M. Heidegger, Bycie i czas, tłum. B. Baran, Warszawa 1994, s. 173n, 256n, 393n, 418n. Lévinas, uznając doniosłość tej analizy, idzie dalej. Zwraca uwagę, że obawa o drugiego wyzwala mnie z obawy o samego siebie i z lęku związanym z byciem-ku-śmierci, „przepełniając” tym samym ontologię Dasein („Obawa o bliźniego, obawa o śmierć drugiego człowieka jest moją obawą, nie jest jednak wcale jakimś przerażaniem się”, EPP, s. 102-103, tłumaczenie własne). Co więcej łączy on tę obawę o drugiego, chęć przyjścia mu z pomocą z miłością: „Kochać znaczy bać się o innego człowieka, przychodzić z pomocą jego słabości” (CN, s. 308).

54 Choć bowiem twarz innego jest przede wszystkim kwestią odpowiedzialności, a nie poznania, źródłem wezwania a nie kontemplacji (por. EN, s. 50, 53; IB, s. 159 i in.), to ostatecznie Lévinas nie zaprzecza, że posiada ona pewną, swoistą nową inteligibilność. Charakteryzuje ją jednak zasadniczo negatywnie, jako opór, jako to, co - w przeciwieństwie do przyrody - opiera się tematyzacji i konstytucji, jednak nie przez przemoc - tak opiera się świat fizyczny - ale przez samą inteligibilność: twarz mówi mi „nie zabijesz”, „nie popełnisz morderstwa” (CN, s. 366). Jednak takie „poznanie” "nie należy ani do dziedziny odsłonięcia formy, ani też do dziedziny irracjonalnego kontaktu”. „Jest ono racjonalne, racjonalnością wcześniejszą od wszelkiej konstytucji” (LC, s. 44-45). Lévinas idzie nawet dalej i charakteryzuje twarz w terminach metafizycznych, jako „istnienie substancji, jakiejś rzeczy-w-sobie”, która wyziera przez formę w spojrzeniu. Nawet jednak taka ogołocona $\mathrm{z}$ wikłających ją z całym światem form i posiadająca bezkontekstualny sens oraz własną „świetlistość” (luisance) twarz nie daje nam poznania jej „właściciela” (por. LC, s. 42-44). Jednocześnie jest bardziej bezpośrednim niż intuicja odniesieniem do tego-co-jest, odsyłając tym 
zasadnie zapytać: jaką relację z innym odkrył Lévinas? Albo inaczej: w jakiej relacji do innego Bóg przychodzi mu na myśl i ją nawiedza? Otóż moja teza jest taka, że nie jest to sensu stricte relacja miłości (przynajmniej żadna z tych, które przytoczyłem na początku), lecz że jest to zasadniczo relacja służby innemu. Służby odpowiedzialnej, aż po oddanie życia. Służby nie tyle obawiającej się drugiego, ile obawiającej się o niego. Służby niejako ojcowskiej, opiekuńczej, „pasterskiej”, a może po prostu męskiej ${ }^{55}$ ?

Dlaczego nie jest to miłość (a przynajmniej jest to miłość niepełna):

- Lévinas zdaje się nie zważać na to, czy inny go kocha - pisze wręcz, że wzajemność usuwałaby darmowość! - każda zaś miłość dąży do wzajemności, chce, by drugi odpowiedział miłością na miłość, choć oczywiście niekoniecznie „działa” ze względu na odwzajemnienie ${ }^{56}$;

- Lévinas nie pozwala też sobie służyć: nie chce, żeby drugi go zastępował $^{57}$. Owszem, niezaprzeczalne jest, że są decyzje, za które odpowiedzialny jestem ja sam i nikt nie może mnie w nich wyręczyć, ale dlaczego nie dopuścić drugiego do struktury aktu etycznego, jako współodpowiedzialnego (choćby po części) za moją egzystencję?;

samym do pełni sensu poprzedzającego wszelką inteligibilność, czyli do samej struktury stworzenia (por. LC, s. 45). Zdaniem Lévinasa również i takie odniesienie jest niemożliwe inaczej niż jako stosunek etyczny. Taką czysto etyczną inteligibilność twarzy poddał krytyce Derrida, zwracając słusznie uwagę, że musi ona zakładać minimum jakiegoś poznania teoretycznego (por. J. Derrida, L'écriture et la différence, Paris 1967, s. 188n). Jest ono, jak się wydaje, warunkiem koniecznym do uprawnionego użycia takich słów, jak „,inny”, „nieskończone”, „pragnienie”, „idea”.

${ }_{55}$ Sam Lévinas bardzo często wspomina o służbie, także w kontekście substytucji: „To co w niej [w twarzy drugiego] brzmi jako prośba, oznacza z pewnością apel do dawania i służenia [...] oraz nakaz niepozostawiania drugiego samemu nawet w obliczu nieuchronności” (EN, s. 65), por. także przyp. 70. Odnosi się wręcz wrażenie, że dla niego prawdziwa egzystencja polega na „ojcowskim” pasterzowaniu innemu. Dlatego ciekawa byłaby hipoteza, że tak naprawdę Lévinas opisuje, nieomówioną nigdzie explicite, figurę dojrzałego mężczyzny: odpowiedzialnego, wrażliwego na cierpienie innych, dającego im i za nich własne życie. Mężczyzny będącego mężem (por. CN, s. 176n), ojcem (por. CN, s. 335n) i bratem (por. IB, s. 276-277). Co do samego „uczucia” obawy o drugiego por. przyp. 53.

56 Wzajemność w relacji międzyosobowej prowadzi według Lévinasa do wątpliwej moralności polegającej na wymianie (por. BNM, s. 176).

57 „Nikt nie może zastąpić mnie, jako tego, który zastępuje wszystkich” (IB, 214). „Inny może zastąpić kogo chce, z wyjątkiem mnie" (BNM, 177). 
- czy Lévinas chce poznać innego? wiedzieć, kim jest? jakie są jego troski? Czy z tym, z którym stoi twarzą w twarz, chce rozmawiać jak przyjaciel z przyjacielem? $\mathrm{Nie}^{58}$. Według niego taka relacja zamykałaby na wszelką transcendencję! ${ }^{59}$;

- Lévinasowska miłość nie pozostawia miejsca na wolność, na odpowiedź: „chcę cię kochać...”, ale raczej zniewala (choć owszem, miłość jakoś zniewala, szczególnie uczuciowa, jednak im jest dojrzalsza, tym „chcę” jest większe, tym większa jest też wolnośćco ${ }^{\prime}$ Poza tym wolność przychodzi także od drugiego, a więc dzięki wzajemności). Oprócz struktury „mogę, nie muszę, chcę" zdaje się istnieć także: „możesz, nie musisz, jeśli chcesz”" ${ }^{\prime \prime}$;

- miłość zostawia miejsce dla inicjatyw, czym raduje kochanego. W substytucji natomiast mamy do czynienia tylko z czystą biernością, z odpowiedzialnością poprzedzającą wszelkie zaangażowanie ${ }^{62}$ (choć i tu Lévinasa można bronić, gdyż zdaje się on mówić o źródłowym, przedświadomym zetknięciu z dobrem, tzw. miłości pierwszej, która faktycznie pozostaje poza zasięgiem naszej wolności ${ }^{63}$. Dlaczego jednak tylko na niej poprzestać?;

- owszem, miłość gotowa jest poświęcić siebie, oddać własne życie (swój byt) za lub dla drugiego, jednak nie jest tym poświęceniem, ale raczej spełnieniem, odpocznieniem, owszem wyrywającym mnie z siebie, ale jednocześnie mnie pogłębiającym. O ile na to drugie Lévinas

58 „Nie jest to poznanie jego charakteru ani jego pozycji społecznej, ani jego konkretnych potrzeb, lecz jego nagość biedaka, nagość zapisana w jego twarzy, twarzy będącej nagością, która wyznacza mnie do bycia odpowiedzialnym i dzięki której dopiero jego potrzeby mogą się dla mnie liczyć” (BNM, s. 183-184).

59 „Gdybym, zamiast zastępować drugiego, czekał, że on zastąpi mnie, byłaby to wątpliwa moralność, ale, co więcej, zniszczyłoby to wszelką transcendencję. Nie można dać się zastąpić w zastępowaniu, podobnie jak nie można dać się zastąpić w umieraniu” (BNM, s. 177).

${ }^{60}$ Por. zasadę „im większa wartość, tym większa wolność” obecną m.in. w etyce Maxa Schelera czy Józefa Tischnera.

${ }_{61}$ Por. K. Wojtyła, Osoba i czyn, Lublin 2000, s. 148.

${ }^{62}$ „Odpowiedzialność, której nie uzasadnia żadne wcześniejsze zaangażowanie” (IB, s. 171); „odpowiedzialność, która nie opiera się na żadnym swobodnym zaangażowaniu” (IB, s. 195).

${ }^{63}$ W tym sensie Lévinas słusznie krytykowałby jakąś formę dobrotliwego, konwencjonalnego czy odruchowego zaangażowania, rozumianego jako „,altruistyczna wola, instynkt «naturalnej życzliwości» lub miłość” (IB, s. 188). 
się zgodzi: moje Ja „powstaje”, gdy jestem dany ${ }^{64}$, o tyle konsekwentnie uważa, że miłość ze swej istoty skupia się na samej sobie, tracąc niejako innego sprzed oczu ${ }^{65}$;

- na koniec jeszcze jedno: wbrew pozorom relacja względem innego nie może być wedle Lévinasa miłością bezinteresowną. Nie mogę kochać innego dla niego samego! Jest to możliwe tylko wtedy, gdy „Upragniony (le Désirable) odsyła mnie... do innego" "66. Sam z siebie bliźni jest natomiast le non-désirable!, l'indésirable par excellence ${ }^{67}$ !;

- powstaje więc pytanie, czy taka relacja z drugim człowiekiem nie jest jakoś iluzoryczna. Skoro nie mogę pragnąć bliźniego, czy nie staje się on tym samym jedynie okazją do prawdziwej relacji z Innym, poniekąd akcydentalnym i ostatecznie, choć uprzywilejowanym miejscem odkrycia Boga, to jednak jakoś w tym odkryciu przeszkadzającym ${ }^{68}$ ?

\section{Czy substytucja jest służbą? Jeśli tak, to jaką ${ }^{69}$}

Czy więc substytucja jest służbą? Na wstępie jedna uwaga: przez służbę rozumiem jakieś działanie, które mając swoją własną treść (konsystencję), zorientowane jest na drugiego jako na beneficjenta tegoż działania. Służba

64 Co więcej, mówi o lekkości i radości płynącej z poddania się Dobru („Pełne lekkości poddanie się Dobru”, IB, s. 214), czego według niego nie należy, rzecz jasna, mylić z satysfakcją i zadowoleniem.

65 „Miłość lubi samo czekanie na Ukochanego, to znaczy cieszy się nim przez reprezentację, wypełniającą czas oczekiwania [...]. W używaniu gubi się bezmiar Pragnienia i miłość staje się pożądliwością w Pascalowskim sensie, dźwiganiem się i panowaniem ja” (BNM, s. 142-143). Por. także CN, s. 306n.

66 BNM, s. 143.

${ }^{67}$ Co można przetłumaczyć jako „to, czego nie da się pragnąć”, „to, czego nie pragnę” ale i jako „ktoś niepożądany” (por. BNM, s. 143).

68 Lévinas nazywa drugiego „właściwym miejscem prawdy metafizycznej, [który jest tym samym] w mojej relacji z Bogiem niezbędny” (CN, s. 79). Nie widzi w nim jednak pośrednika między człowiekiem a Bogiem czy tym bardziej Jego ucieleśnienia/wcielenia, ale „ukazywanie wyżyn, na jakich objawia się Bóg", i to właśnie przez twarz, w której drugi jest odcieleśniony/bezcielesny (désincarné)! (por. CN, s. 79).

69 Por. „Wyjście poza egzystencję fenomenalną lub wewnętrzną nie polega na byciu uznanym przez Innego, ale na ofiarowaniu mu własnego bytu. Być w sobie to wyrażać się, a zatem służyć już Innemu. Na dnie ekspresji leży dobroć” (CN, s. 215). 
nie będzie więc w żadnej mierze wykluczała relacji miłości, wręcz przeciwnie, będzie mogła z niej wypływać jako jej owoc (gdy kocham, chcę służyć drugiemu, jestem tym, na kogo drugi może najbardziej liczyć), będzie też mogła do niej przygotowywać (niewątpliwie niesiona pomoc, usłużenie są uprzywilejowanym miejscem dostrzeżenia ludzkiej dobroci rysującej się na twarzy innego, i pokochania go), choć nie będzie koniecznie z nią związana (a przynajmniej z jej najdoskonalszą postacią: usługa szewska czy medyczna nie wymaga przyjaźni, ale pewnej życzliwości i szacunku tak). Służenie wnosi element zewnętrznego działania, czyli szeroko rozumianej ludzkiej poiesis. Stąd więc można sobie zadać pytanie, czy substytucja nie jest jakąś formą służenia, a może i jednak jakąś miłością służebną, np. ojcowską, czy też miłością sługi (niewolnika) do pana ${ }^{70}$.

Otóż istnieją takie typy służby, które wymagają pewnego zadysponowania całym sobą, co w niektórych sytuacjach może się wiązać się nawet z zaryzykowaniem własnym życiem. Oprócz wspomnianej relacji pan-niewolnik, w której pan ze względu na nieumiejętność roztropnego prowadzenia się przez niewolnika zastępuje niejako jego roztropność, istnieje też relacja ojciec-dziecko oraz matka-dziecko, w których z jednej strony ojciec najczęściej ryzykuje życie, broniąc rodziny w sytuacjach zagrożenia fizycznego (co ma przedłużenie w służbie wojskowej), z drugiej zaś strony matka ryzykuje własne życie, wydając dziecko na świat (przedłużeniem czego jest częste poświęcenie się w wychowaniu). Obydwie te postawy mają charakter służby - wiążą się ściśle z realizacją pewnego dzieła - i to służby niejako substancjalnej, dotykającej całego człowieka: bez możliwości poniesienia tego ryzyka zdają się one tracić swój własny charakter. I choć obecna jest w nich w sposób oczywisty i determinujący miłość, nie jest to miłość pełna, ale - można by

70 Bez wątpienia jest to jakaś forma diakonii-służby drugiemu (por. BNM, s. 252), czy wręcz poddania się drugiemu jako Panu (por. CN, s. 253). Jednak jak sam stwierdza, chodzi mu o „służbę bez niewolnictwa” (IB, s. 95), a więc nie o niewolnictwo z przemocy, ale poddanie się dobru: „Dobroć jest w podmiocie tym, co an-archiczne. Jest odpowiedzialnością za wolność innego poprzedzającą wszelką wolność we mnie, ale także poprzedzającą przemoc wobec mnie, będącą przeciwieństwem wolności, bo chociaż nikt nie jest dobry z własnej woli, nikt też nie jest niewolnikiem Dobra" (IB, s. 231-232). 
rzec - fundamentalna. Każda miłość zdaje się bowiem dążyć do jakiejś równości między miłującymi się osobami. Tutaj zaś kochany jest z natury słabszy, potrzebujący pomocy.

Inne pytanie: czy takie posługi są dobrowolne? W ścisłym tego słowa znaczeniu nie wybieram sobie dziecka, ale je w dużej mierze zastaję: nie ma tu więc wolności, która może charakteryzować np. przyjaźń.

Podobnie jest z poznaniem: sługa nie zna najgłębszych intencji swojego pana. $Z$ drugiej strony służąc drugiemu, nie jestem zobowiązany do tego, by się z nim dzielić swoimi najgłębszymi intencjami. Nawet dziecko nie musi znać sekretów ojca czy matki.

A jak jest w spotkaniu z innym? Czy chcę poznać innego z bliska, dzielić jego życie, wybrać go w sposób wolny? Czy do tego wszystkiego „przymusza mnie twarz innego”? Owszem, zmusza jakoś do szacunku, do sprawiedliwości, jednak niekoniecznie od razu do miłości. Chyba że do religijnego miłosierdzia. Jednak i tam, jak jeszcze o tym wspomnę, istnieje otwarcie na wzajemność.

Czy nie można więc powiedzieć, że u Lévinasa postawą względem innego jest nie tyle postawa miłości, co właśnie służby, i to aż po śmierć? Albo inaczej: byłaby to miłość religijna, $\mathrm{z}$ akcentem na specyficzną służbę wobec drugiego. Jednak miłość jakoś niepełna, zredukowana do samego zobowiązania, do samej odpowiedzialności za drugiego, także za jego śmierć (czyż żyjąc dla siebie nie zabijam innych...? czy nie pozbawiam się prawa do życia tkwiąc w zamknięciu we własnym usatysfakcjonowanym, przestraszonym, zaspanym ja? - pyta Lévinas ${ }^{71}$ ).

Na końcu warto spojrzeć na Lévinasowską substytucję w świetle biblijnej historii zbawienia. Szczególnie interesująca tu będzie postać cierpiącego sługi, łącząca się z oczekiwaniem na Mesjasza.

Idea mesjasza ${ }^{72}$ - czyli namaszczonego przez Boga - pierwotnie wiązała się z postacią izraelskiego króla. Namaszczenie jego głowy olejem symbolizowało spłynięcie na niego i wzięcie go w posiadanie przez Ducha

71 Por. EN, s. 66-67.

72 Idę tu za: Mesjasz, [w:] X. Léon-Dufour, Słownik teologii biblijnej, tłum. K. Romaniuk, Poznań 1994, s. 467-472. 
Bożego po to, by sprawował funkcję Bożego namiestnika w Izraelu ${ }^{73}$. Po upadku dynastii Dawidowej pomazańcami Pańskimi zwano niektórych proroków, władców, a wreszcie kapłanów, którzy - przy braku króla sprawowali najwyższą funkcję społeczną, nie tyle jednak doczesną, ile religijną. Wobec upadku Królestwa Izraela, a także pewnego „upadku” kapłaństwa, liczne proroctwa mesjańskie zaczęto odczytywać eschatologicznie: czekano więc na Mesjasza-króla, w niektórych środowiskach czekano też na Mesjasza-arcykapłana ${ }^{74}$. Postać tę wiązano także z wizją proroka Daniela mówiącą o przyjściu Syna Człowieczego. Jednym słowem, oczekiwano wybawienia i odkupienia Izraela. Szczególnie mocne na tym tle okazywało się proroctwo Izajaszowe mówiące o Słudze, który weźmie na siebie cierpienia i grzechy tego wybranego przez Boga narodu ${ }^{75}$. Tak jak wypędzane na pustynię w czasie święta Jom Kippur zwierzę (najczęściej kozioł) obarczane było grzechami wspólnoty Izraela, tak też miał je na siebie wziąć ów Sługa, uznając się poniekąd za winnego, stając się „kozłem ofiarnym” ginącym na pustyni, by „usprawiedliwić” zgromadzenie.

Tyle Biblia, Stary Testament. Powstaje pytanie o to, czy - a raczej w jakim stopniu - jedną z inspiracji Lévinasowskiej substytucji - jeśli nie jedyną - jest właśnie idea mesjańska: wzięcie na siebie win bliźniego, jego cierpienia - zresztą nie bez związku z uprzednim byciem dotkniętym przez Boga (namaszczeniem do tej kapłańskiej funkcji?), które się niejako „aktualizuje” przy każdym spotkaniu twarzy innego ${ }^{76}$. Inny mówi

73 Por. 1 Sm 9, 16; 10, 1. 10; 16, 13.

74 Kwestia, czy mesjasza należało rozumieć zbiorowo czy indywidualnie, jest dla nas $\mathrm{w}$ tym momencie drugorzędna. Interesuje mnie tu sama mesjańska postawa. O tym, jak interpretuje biblijną postać mesjasza Lévinas, zob. przyp. 76 .

75 Por. Iz $52-53$.

76 Biblijne korzenie substytucji dość obszernie pokazuje Lévinas w komentarzach do tekstów mesjańskich w Trudnej wolności (s. 60-100). Zdaje się on rozumieć postać mesjasza ni to zbiorowo (np. utożsamiając go narodem wybranym), ni to indywidualnie (jako jakiegoś jednego, konkretnego Mesjasza, który przyszedł, czy też miałby nadejść). Widzi go raczej jako samą, „metafizyczną" strukturę człowieka, jako osobiste powołanie każdego człowieka (por. TW, s. 91). Lévinas pisze: „Każdy musi postępować tak, jak gdyby był Mesjaszem” (TW, s. 93), a nawet: „Mesjasz to Ja, być Ja to być Mesjaszem” (TW, s. 93) i dalej: „Fakt nieuchylania się przed ciężarem, jaki narzuca cierpienie innych, określa samą ipseitas. Wszystkie osoby są Mesjaszem”. Do tego przypisu nawiążę 
więc nie tylko: „nie zabijesz mnie”, ale także „nie zostawiaj mnie samego”, „pomóż mi być”, a raczej „pomóż mi przejść do inaczej niż być”. Okazuje się bowiem, że zabija również (a może przede wszystkim) wszelka egzystencja obojętna, nie-bierna wobec napotkanej twarzy ${ }^{77}$.

Taka postawa przywołuje oczywiście na myśl także postać Jezusa z Nazaretu, w którym chrześcijanie rozpoznają wyczekiwanego Mesjasza. Święty Jan pisał o nim jako o „Baranku Bożym, który gładzi grzech świata” (por. J 1, 29), sam zaś Jezus podkreśla, że „nie przyszedł, aby $\mathrm{Mu}$ służono, lecz by służyć i dać swoje życie na okup za wielu” (Mk 10, 45), wypełniając przy tym wielokrotnie Izajaszowe proroctwa cierpiącego Sługi Pańskiego ${ }^{78}$. Święty Paweł wyraził to zwięźle w przywoływanym już fragmencie z Listu do Filipian, pisząc o Nim jako o Synu Bożym, który „przyjąwszy postać sługi [...] uniżył samego siebie, stawszy się posłusznym aż do śmierci" (2, 6-8). Trudno o kogoś, kto lepiej niż Jezus wpisałby się w Lévinasowską „logikę twarzy”, zwłaszcza że nierozerwalnie związał się właśnie z potrzebującymi: „Wszystko, coście uczynili jednemu z tych braci moich najmniejszych, Mnieście uczynili” (Mt 25, 40).

Jest jednak jedno ale: Jezus, w relacji św. Jana, przekracza wymiar służby, zapraszając swoich uczniów do nowej bliskości. Mówi wyraźnie: „Już was nie nazywam sługami, bo sługa nie wie, co czyni pan jego, ale nazwałem was przyjaciółmi, albowiem oznajmiłem wam wszystko, co usłyszałem od Ojca mego" (J 15, 15). Sam zaś Jan Ewangelista nazywa siebie dyskretnie uczniem, którego Jezus miłowal ${ }^{79}$.

Przekroczenie służby w przypadku Jezusa nie oznacza jej zanegowania. Jako Boski przyjaciel prosi swoich bliskich o rozmaite przysługi ${ }^{80}$, a tak-

jeszcze przy końcu moich rozważań. Natomiast na temat aktualizacji „kapłańskiego namaszczenia” w spotkaniu z twarzą por. przyp. 28.

77 A także wszelka myśl, która neutralizuje Innego, czyniąc zeń przedmiot, temat, redukując go tym samym do Tożsamego (por. CN, s. 30). Por. także, choć w innym kontekście IB, s. 293.

78 Łk 4, 17-21; Łk 22, 37; Mt 8, 17; 12, 17-21; J 12, 38-41; Dz 8, 32-35; Rz 4, 25; 15, 21; 1 Kor 15, 3; 2 Kor 5, 21; 1 P 2, 22-25; Ap 5, 6 itp.

79 Poza tym Jezus sam siebie nazywa przyjacielem Łazarza (J 11, 11), zaś Jan Chrzciciel mówi o sobie jako o „przyjacielu oblubieńca” (J 3, 29).

80 Np. „Paś baranki moje [...]” (J 25, 15-17); „Idźcie i czyńcie uczniów [...]” (Mt 28, 19); „Oto syn twój [...], oto matka twoja” (J 19, 26-27). 
że - co paradoksalne - daje uczniom przykazanie miłości $(J 15,12)$. To jednak miłość, a nie służba jest Jego ostatnim słowem, ostatnią prośbą, przed podjęciem Męki $(J$ 17, 26). To o nią przede wszystkim Mu chodzi. Tuż przed śmiercią woła „Pragnę”, zaraz po tym, gdy stwierdził, że wszystko zostało już spełnione (tetelestai)! Potem dopiero, powtarzając: „spełniło się" (tetelestai), oddaje/przekazuje ducha i daje sobie otworzyć włócznią serce (por. J 19, 28-30).

Po co o tym mówię? By pokazać, że w samej misji Jezusa należy wyróżnić dwa porządki: służbę i miłość. Jezus bowiem - jeśli uznać, że był Mesjaszem - wychodzi niejako poza mesjański porządek. Jest nie tylko tym, który dokonuje dzieła odkupienia, będącego de facto dziełem miłosierdzia..., ale idzie dalej: staje się Oblubieńcem, zapraszając do jedności, do wybrania, do tego, by żyć Jego miłością (agape), by kochać tak jak $\mathrm{On}^{81}$. Dopełnia więc służbę szaloną miłością, choć - jak się wydaje w ścisłym tego słowa znaczeniu aż takiej miłości żadna - nawet mesjańska - służba nie wymaga ${ }^{82}$.

Rozróżnienie to nie przeciwstawia się rzecz jasna wzajemnemu przenikaniu się miłości i służby: pozwala jedynie lepiej uchwycić oba te, nieraz bardzo mocno splecione ze sobą, momenty. Jak już wspomniałem w każdej posłudze, a w sposób szczególny w posłudze „religijnego" miłosierdzia, jakaś forma miłości jest nieodzowna. Jej „technicyzacja” (polegająca na wyłącznym skupianiu się na targecie, jakim jest zaradzenie złu czy słabości drugiego) prowadzi ostatecznie do jej karykatury: chęci jak najskuteczniejszego, najlepiej natychmiastowego, usunięcia trudności przy pominięciu tego, co najistotniejsze - samego cierpiącego człowieka. Jak pisze wspomniany już Philippe: „Akt miłosierdzia jest moralnie dobry tylko wtedy, gdy jest wyrazem aktualnej miłości do tego, komu

$81 \mathrm{~J} 13,34 ; 17,26$.

82 Stąd też św. Tomasz z Akwinu nazywa miłość-agape jakąś przyjaźnią (Summa theologiae, II-II, 23, 1), zaś zbawienie i odkupienie zwane jest dziełem (opus, ergon) (por. Łk 4, 43; J 5, 17; J 10, 16). Oczywiście miłość-agape nie wyklucza służby, wręcz przeciwnie do niej przynagla, w niej się przejawia i nawet jej wymaga, gdy drugi jest w potrzebie. Jednak nie do niej ostatecznie zmierza. Dąży do zjednoczenia i do otwartej na innych wzajemności. 
mamy ulżyć w cierpieniu"83. Dlatego też prawdziwe miłosierdzie, choć jeszcze przyjaźnią nie jest, pozostaje zawsze otwarte na coś więcej niż pomoc. Tym bardziej w przypadku miłosierdzia religijnego, które jest owocem zwrócenia się i czerpania z samego Źródła miłości: jest więc miłości nadmiarem. Taką drogą poszło wielu. Podąża nią - docierając jednak dużo dalej, bo biorąc na siebie "grzech świata” - także i Jezus.

Wreszcie można i trzeba ostatecznie zapytać, czy tak rozumiana służba, a więc wzięcie na siebie win/grzechów innych ludzi ma w ogóle jakiekolwiek - nawet szeroko rozumiane - ludzkie znaczenie i sens. Czy i kiedy mogę na siebie brać winy innych? Kiedy mogę brać za innego odpowiedzialność ${ }^{84}$ ? Czy nie wtedy i w takiej mierze, w jakiej mam na kogoś wpływ, w jakiej mogę coś zrobić dla drugiego, w jakiej mogę chociaż mu współczuć... inaczej wydaje się to być działanie na próżno ${ }^{85}$. Te trzy elementy obecne są zaś najpełniej właśnie we wspomnianej przeze mnie perspektywie miłosierdzia, w której i tak - ściśle rzecz biorąc - nie biorę na siebie win drugiego, ale ich konsekwencje. Czy nie oznacza to jednak, że nie staję się nigdy odpowiedzialny za wszystko w drugim, za całego drugiego? Żeby to było w ogóle możliwe, musiałbym być jego źródłem, źródłem jego „ja”. Musiałbym być dla drugiego Bogiem. Jedynym wyjściem jest powiedzieć - i tu Lévinas mógłby być

$83 \quad$ AM, s. 238.

84 Tutaj należałoby jeszcze wspomnieć o różnicy, której Lévinas zdaje się nie robić, pomiędzy winą a powinnością: o ile pierwsza zakłada jakąś niesprawiedliwość i krzywdę, o tyle druga może nie odnosić się do wyrządzonego zła, a jedynie do rozpoznanego dobra.

85 Pomijam tu oczywiście kwestię, czy i do jakiego stopnia mam prawo dysponować sobą, co należałoby rozpatrzyć tak z perspektywy miłości własnej versus miłości bliźniego, jak i z perspektywy religijnej, w której nie do końca jestem swoją własnością. Jeśli chodzi o miłość własną, to o ile mi wiadomo, jednym z nielicznych miejsc, w którym Lévinas pisze może nie tyle o niej, co o sprawiedliwości wobec samego siebie, jest IB, s. 218: „Ja może zostać wezwane w imię tej nieograniczonej odpowiedzialności do tego, by zatroszczyć się również o siebie". Zdaje się bronić natomiast przed nią w BNM, s. 173n, gdzie oryginalnie interpretuje przykazanie miłości bliźniego, uważając, że „kochaj bliźniego jak siebie samego” nie odnosi się do miłości własnej i należy je rozumieć jako „kochaj bliźniego twego... ta miłość jest tobą samym”. Jeszcze ostrzej ocenia własne pour soi, utożsamiając je jednoznacznie z egoizmem i czymś godnym nienawiści (CN, s. 91). Całą tę koncepcję łagodzi mimo wszystko kobiecość, umożliwiająca zrywające z „dla siebie” dyskretne przebywanie własnego ja „u siebie” (CN, s. 173-181). Por. także przyp. 52. 
spójny - że tak, jak dzięki innemu staję się prawdziwym „mną”, tak tė̇ dzięki mnie, jako innemu, drugi staje się wreszcie sobą. W tym sensie jestem mu wszystko winien („je lui dois tout”), jestem mu winien jego samego, jego własne „wszystko" ${ }^{86}$. Czy jednak tak rozumie to Lévinas? Czyż nie idzie dalej? Czy w owym tout nie zawierają się wszyscy ludzie (także ci niespotkani), ba - cały wszechświat? Odpowiedzialność jest przecież u niego nieskończona. Także i inny jest ze swej istoty nieskończony $^{87}$. A więc: czy nie powinienem być odpowiedzialny za całego innego, także za jego umysł i wolę - przecież mam brać na siebie jego winy! Idąc dalej: czy nie powinienem odpowiadać za niego jako za tożsamego? A za jego bycie (choćby było ono niepełne i tylko „ontologiczne”) i za jego substancję, do której - jak pisał niegdyś Lévinas - mam dostęp w twarzy drugiego ${ }^{88}$, a która ukazuje w innym strukturę stworzenia ${ }^{89}$ ? Wszystkie te pytania należałoby Lévinasowi zadać ${ }^{90}$. Przecież na szalę rzuca całego siebie: swoje własne „wszystko”, własne „ja”91, własną

86 Trzeba by tu rozpatrzyć bardzo ciekawą kwestię różnicy między tout a totalité, które w języku francuskim mają się do siebie jak przymiotnik i pochodzący odeń rzeczownik. Czyż mówiąc ,je lui dois tout”, nie mamy do czynienia z jakąś nową całością? A może odnajdujemy tu prymat konkretu przed abstraktem, analogiczny do pierwszeństwa l'étant przed l'être? Por. CN, s. 30n.

87 „[Inny] staje przede mną jako twarz, kwestionuje mnie i zobowiązuje mnie swoją istotą nieskończoności” (CN, s. 244).

88 „Twarz to uobecnianie się jestestwa jako jestestwa, jego osobiste uobecnianie się. Twarz nie odkrywa jestestwa, ani go też nie zakrywa. Ponad, charakterystycznymi dla formy, odsłanianiem i skrywaniem się, twarz jest ekspresją, istnieniem substancji, rzeczy w sobie, kath' auto" (LC, s. 42). Por. także CN, s. 42, 215, 315 .

89 „Ów sens poprzedzający Sinngebung, owa pełnia sensu wcześniejsza niż wszelka Sinngebung, pozostający jednak relacją intelektu, relacją bez przemocy - on właśnie opisuje strukturę samego stworzenia. [...] Nie jest to teza teologiczna: do idei stworzenia dochodzimy, wychodząc od doświadczenia twarzy" (LC, s. 45).

90 Jak już wspomniałem (przyp. 27), Lévinas nazywa Ja „podporą wszechświata” (le support de l'univers), co więcej widzi w nim tego, kto nadaje sens samemu bytowi. Nie mówi jednak, kto odpowiada za ontologiczną strukturę tożsamego, tudzież tego co nie-osobowe, fizyczne, a dlaczego nie - ewentualnie - samego Boga. Z etycznego punktu widzenia natomiast przyznaje, że choć niesienie win drugiego konstytuuje konkretne ja, to paradoksalnie nie jest ono tak naprawdę do tego zdolne (por. przyp. 39)! Czy nie można by więc powiedzieć, że Lévinasowski człowiek-mesjasz, choć usensawnia świat, to ostatecznie jest nieskuteczny: nie gładzi jego winy?

${ }_{91}$ Por. cytowany już fragment o diakonii własnego ja (BNM, s. 252). 
wolnośćc ${ }^{22}$, własną substancję ${ }^{93}$. Wówczas okazałoby się być może, że do substytucji - w najmocniejszym znaczeniu tego słowa - powołany mógłby być jedynie Bóg, miłujący Stwórca wszystkiego ${ }^{94}$. Jedynie On mógłby być Mesjaszem...

A człowiek? Człowiek może być tylko i aż Jego świadkiem, martyrosem, męczennikiem ${ }^{95}$. Takim świadkiem, aż po śmierć, chce być właśnie Lévinas ${ }^{96}$.

Czy jednak nie dlatego, że w „je lui dois tout”, lui powinno być pisane wielką literą?

92 Por. przyp. 20.

93 Lévinas mówi wyraźnie o substytucji, że jest to „de-substancjalizacja podmiotu, jego od-rzeczowienie, bezinteresowność poddania - jego podmiotowość” (IB, s. 216).

94 Ciekawą, choć zgoła inną możliwość, można znaleźć u Josepha Ratzingera we Wprowadzeniu w chrześcijaństwo (tłum. Z. Włodkowa, Kraków 1994). Otóż do substytucji rozumianej jako zastępstwo mógłby być powołany także przedstawiciel danej wspólnoty: ten który służy jej, królując. „Reprezentować - pisze przyszły papież - znaczy: stawać za innych, zastępując ich” (s. 211). Jedynie król-dziedzic wszystkiego, a więc dziecko-sługa Boży (pais Theou), będący jednoczenie „ostatnim człowiekiem” (eschatos Adam), czyli człowiekiem-wzorem przekraczającym granice człowieczeństwa w całkowitym „byciu dla drugiego” (s. 227), jedynie ktoś taki - będąc całkowitym wolnym „tak” zarówno dla Boga, jak i dla każdego człowieka oraz wszystkich ludzi - może prawdziwie ofiarować samego siebie za innych i zamiast nich, pociągając ich za sobą (s. 280nn). Właśnie takiego zastępstwa dokonał, według Ratzingera - Jezus Chrystus: choć nie był lewitą, stał się prawdziwym kapłanem, który przyszedł z posługą pojednania ludzkości z Bogiem.

95 Lévinasa oczywiście nie zadowala bycie świadkiem, ani nawet bycie prorokiem! Od siebie, ale i od każdego wymaga bycia mesjaszem (por. przyp. 76)! Paradoksalne jest to, że poruszając się w porządku stworzenia, de facto przeczy temu porządkowi, biorąc na siebie odpowiedzialność, którą można by obarczyć tylko Boga-Stwórcę. Porządek stworzenia zdaje się być zatem pełniej zachowany dzięki ordo salutis, w którym mesjaszem staje się sam Bóg, niż - jak chce tego np. Adam Hernas - dzięki wycofaniu się Boga ze świata, pozostawiając jego losy wyłącznie człowiekowi (kabalistyczna koncepcja cimcum). Czy taki wycofany Bóg bierze na siebie winę świata? Czy staje się zakładnikiem innego, człowieka? (por. A. Hernas, Człowiek poza istnieniem, Kraków 2011, s. 58). Być może. Być może właśnie taką mesjańską naturę odsłonił Najwyższy Lévinasowi, a ten - zgodnie z biblijnym wezwaniem: „Świętymi bądźcie, bo Ja jestem święty!” (Kpł 11,44) „naśladuje” Go, stając się mesjaszem dla każdej napotkanej twarzy. Niewinnie cierpiącym sprawiedliwym na wzór Sprawiedliwego. O takim doświadczeniu - o ile mi wiadomo - Lévinas jednak nie wspomina. Nie znaczy to jeszcze, że nie miało ono miejsca.

96 Takim świadkiem chciała być także Edyta Stein, która jako Benedykta od Krzyża, uważała, że im bardziej ktoś bogaty jest miłością Bożą, tym sposobniejszy jest do wstawienniczego zastępstwa. Jej poświęcenie się Bogu zdominowane było właśnie ideą ofiarności zastępczej, czyli ekspiacji za cudze grzechy (por. M. Zawada, Oblicza miłości w życiu i pismach św. Edyty Stein, [w:] Uderz 


\section{Bibliografia}

Adamska J. I., Mądrość miłości. Rzecz o duchowości Edyty Stein, Tczew-Pelplin 1998.

Derrida J., L'écriture et la différence, Paris 1967.

Dostojewski F., Bracia Karamazow, Warszawa 1984.

Grignion de Monfort L.-M., Traktat o prawdziwym nabożeństwie do Najświętszej Maryi Panny, Warszawa 1996.

Heidegger M., Bycie i czas, tłum. B. Baran, Warszawa 1994.

Hernas A., Człowiek poza istnieniem, Kraków 2011.

Jan od Krzyża, Dzieła, tłum. B. Smyrak, Kraków 1986.

Léon-Dufour X., Słownik teologii biblijnej, tłum. K. Romaniuk, Poznań 1994.

Lévinas E., Całość i nieskończoność. Esej o zewnętrzności, tłum. M. Kowalska, Warszawa 2002.

Lévinas E., Éthique comme philosophie première, Paris 1998.

Lévinas E., Etyka i Nieskończony, tłum. B. Opolska-Kokoszka, Kraków 1991.

Lévinas E., Inaczej niż być lub ponad istota, tłum. P. Mrówczyński, Warszawa 2000.

Lévinas E., Le temps et l'autre, Paris 1991.

Lévinas E., Liberté et commandement, Montpelier 1994.

Lévinas E., O Bogu, który nawiedza myśl, tłum. M. Kowalska, Kraków 2008.

Lévinas E., Substytucja, [w:] Filozofia odpowiedzialności XX wieku, red. J. Filek, Kraków 2004, s. 215-235.

Lévinas E., Trudna wolność, tłum. A. Kuryś, Gdynia 1991.

Philippe M.-D., Filozoficzne pielgrzymowanie. List do przyjaciela, tłum. K. Kaczmarczyk, Lublin 2003.

Philippe M.-D., La philosophie de l'activité morale, mps, Rimont.

Philippe M.-D., Retour à la source, t. 1 i 2, Paris 2005 i 2009.

o kamień a wytryśnie mądrość. Rzecz o Edycie Stein, Kraków 2002, s. 84). Pisała: „Jeżeli można swe zasługi ofiarować komuś drugiemu, złożyć je za niego przed tronem Bożym, to można również wziąć na siebie czyjąś winę, tzn. ofiarować się Bogu za tego, na kogo ma przyjść kara” (za: J. I. Adamska, Mądrość miłości. Rzecz o duchowości Edyty Stein, Tczew-Pelplin 1998, s. 120-121). Taka postawa jest u niej wyrazem wiedzy krzyża, która nie jest czystą teorią, ale żywym poznaniem Boga, prowadzącym do miłosnego zjednoczenia z Nim oraz do wypływającej zeń służby, jaką jest współpraca z Bogiem w zbawianiu dusz na wzór ukrzyżowanego Jezusa-Mesjasza (por. E. Stein, Wiedza krzy$\dot{z} a$, tłum. J. I. Adamska, Kraków 1994, s. 307). 
Ratzinger J., Wprowadzenie w chrześcijaństwo, tłum. Z. Włodkowa, Kraków 1994.

Stein E., Wiedza krzyża, tłum. J. I. Adamska, Kraków 1994.

Tatranský T., A reciprocal asymmetry? Levinas's ethics reconsidered, „Ethical Perspectives” 15 (2008) issue 3, s. 293-307.

Tomasz z Akwinu, Summa contra gentiles.

Tomasz z Akwinu, Summa theologiae.

Wojtyła K., Osoba i czyn, Lublin 2000.

Zawada M., Oblicza miłości w życiu i pismach św. Edyty Stein, [w:] Uderz o kamień a wytryśnie mądrość. Rzecz o Edycie Stein, Kraków 2002, s. 76-85. 